ISSN 2076-0787

www.mdpi.com/journal/humanities

Article

\title{
Inquiring into Red/Red Inquiring
}

Ken Gale $^{1, *}$, Mike Gallant ${ }^{2}$, Susanne Gannon ${ }^{3}$, Davina Kirkpatrick ${ }^{4}$, Marina Malthouse ${ }^{5}$, McClain Percy ${ }^{6}$, Maud Perrier ${ }^{7}$, Sue Porter ${ }^{8}$, Ann Rippin ${ }^{9}$, Artemi Sakellariadis ${ }^{10}$, Jane Speedy ${ }^{11}$, Jonathan Wyatt ${ }^{12}$ and Tess Wyatt ${ }^{13}$

1 Faculty of Health Education and Society, School of Education, University of Plymouth, Nancy Astor Building, Drake Circus, Plymouth, PL4 8AA, UK

2 Centre for Lifelong Learning, University of Warwick, Westwood Campus, Coventry, CV4 7AL, UK; E-Mail: mike.gallant@warwick.ac.uk

3 Centre for Educational Research, School of Education, University of Western Sydney, Locked Bag 1797, Penrith South DC, NSW 2751, Australia; E-Mail: S.Gannon@uws.edu.au

4 PLaCE Research Centre, Faculty of Creative Arts, University of the West of England, Bower Ashton Campus, Kennel Lodge Road, Bristol, BS3 2JT, UK;

E-Mail: davina2.kirkpatrick@live.uwe.ac.uk

5 Dorothy House Hospice, Winsley, Wiltshire, BA15 2LE, UK;

E-Mail: marina.malthouse@dorothyhouse-hospice.org.uk

6 Graduate School of Education, University of Bristol, 35 Berkeley Square, Clifton, Bristol BS8 1JA, UK; E-Mail: mcclain311@gmail.com

7 School of Sociology, Politics and International Studies, University of Bristol, 11 Priory Road, Clifton, Bristol, BS8 1TU, UK; E-Mail: maud.perrier@bristol.ac.uk

8 Norah Fry Research Centre, School for Policy Studies, University of Bristol, 8 Priory Road, Bristol, BS8 1TZ, UK; E-Mail: sue.porter@bristol.ac.uk

9 Department of Management, University of Bristol, 8 Woodland Road, Bristol, BS8 1TN, UK; E-Mail: Ann.Rippin@bristol.ac.uk

${ }^{10}$ Centre for Studies on Inclusive Education, The Park Centre, Daventry Road, Bristol BS4 1DQ, UK; E-Mail: artemi@csie.org.uk

11 Narrative Inquiry Centre, Graduate School of Education, University of Bristol, 35 Berkeley Square, Bristol, BS8 1JA, UK; E-Mail: Jane.Speedy@bristol.ac.uk

12 Oxford Learning Institute, University of Oxford, Littlegate House, 16/7 St Ebbes St, OX1 1PT, UK; E-Mail: jonathan.wyatt@learning.ox.ac.uk

13 Larkmead School, Oxford Brookes University, Faringdon Road, Abingdon, OX14 1RF, UK; E-Mail: tessa.wyatt2@gmail.com

* Author to whom correspondence should be addressed; E-Mail: kjgale@plymouth.ac.uk; Fax: 01752233829. 
Received: 21 December 2012; in revised form: 20 May 2013 / Accepted: 21 May 2013 /

Published: 23 May 2013

\begin{abstract}
This layered account of an inquiry into 'red' emerged out of a collective biography workshop. In the middle of the Wiltshire countryside, an international and interdisciplinary group of scholars gathered together to write and make other things and marks on paper that asked questions of, and into, the spaces between words, people, things and their environments. We did not set out to workshop or write into or paint 'red' but, rather, it was red that slipped in, uninvited, and painted and wrote us. Red arose as a blush or a stain seeping amongst us that became referenced obliquely by material objects, metaphors and fairytales. The stain spread, became noticeable through our weekend together and beyond it, creating another (bright red artery) vein of connection to write with.
\end{abstract}

Keywords: collective biography; layered accounts; human-nonhuman entanglements; collaboration; desire; agential and magical realisms

\title{
1. Introduction
}

In this paper we take up the challenge of 'art and words' to conduct a multi-authored, multimodal experiment in writing through red. With thirteen authors, the orchestration of the writing of this paper without a single authoritative 'conductor' was often complex and always surprising. Rather we endeavoured to create a textual space where individual subjectivities and authorial voices emerge, merge, and disappear, to emerge again in different configurations and rhythms. So too, art and words intersect and infect each other. This space of collaborative writing and communal inquiry interrupts many of the norms of scholarly writing and the audit practices of our institutions that require academic authorship to be counted by our individual contributions ${ }^{1}$. Instead this project became a 'wondering' and a 'wandering' around how we might write and work otherwise collaboratively.

Likewise we desired a way to write stylistically and rhetorically disentangled from the norms of authorship when following our shared interests in narrative as a method of inquiry. The methodology of collective biography provided us with strategies for collaboratively investigating subjectivities, discourse and materiality in lived experience through memory [1]. A weekend in October 2012, spent together in Ammerdown, a country estate in Wiltshire, UK served as our starting point, although our inquiries - and our processes of writing and art-making - took us to new spaces and opened new possibilities. The narratives in this paper are composed of memories and fictions and, rather than reifying the individual subject and the separateness of these texts, they bump against, inform and interrupt each other, as they did in our workshop. Our process and our writing seeks a mode of

1 See special issue of International Review of Qualitative Research (Vol. 5, No. 4, 2012) on collaborative writing edited by Ken Gale and Jonathan Wyatt for detailed discussions on the ethics and practices of collaborative writing in the academy. 
production that opens to the elusive movements of affect and matter, and that enables us to begin to map the "thicket of connections" between things ([2], p. 72). The paper's structure follows some tropes of narrative time and space with a loosely chronological organisation (a 'beginning', a 'middle' and an 'end') that is populated with distinct narrative voices and 'characters' rather than an abstract voice from nowhere. The paper is infused with details of the everyday matter of our lives, the settings within which each of us grappled with the text, and with thought and theory that might assist our thinking. The colour red became our rhetorical thread and throughout the text literary strategies including recurring motifs, poetry and elements of magical realism, and visual strategies including changes of font and section breaks, link our textual fragments together.

Images are central to our method as it was through image-making that our inquiries turned to materiality, to the very matter of red. We collaborated in one session to produce a long red collage with paint and glue and ink and text where fragments, motifs, and both found and sculptured objects, cross across and through each other. We began in our own corners, but as in other phases of our process, we gained confidence and began to move along, between and across, to create and intensify reverberations and resonances. This was "a doubling", where art and words "complement, extend, refute, and/or subvert one another" ([3], p. 900). We pushed method and writing towards the sort of productive failure that might mark their limits, and the possibilities of working otherwise.

Figure 1. Ammerdown collective scroll: purposeful play with red I.

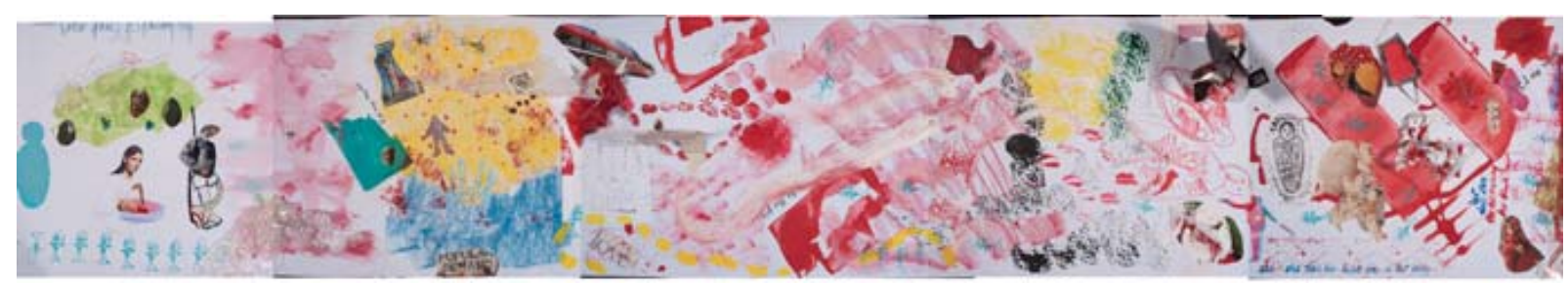

Figure 2. Red collage shards.

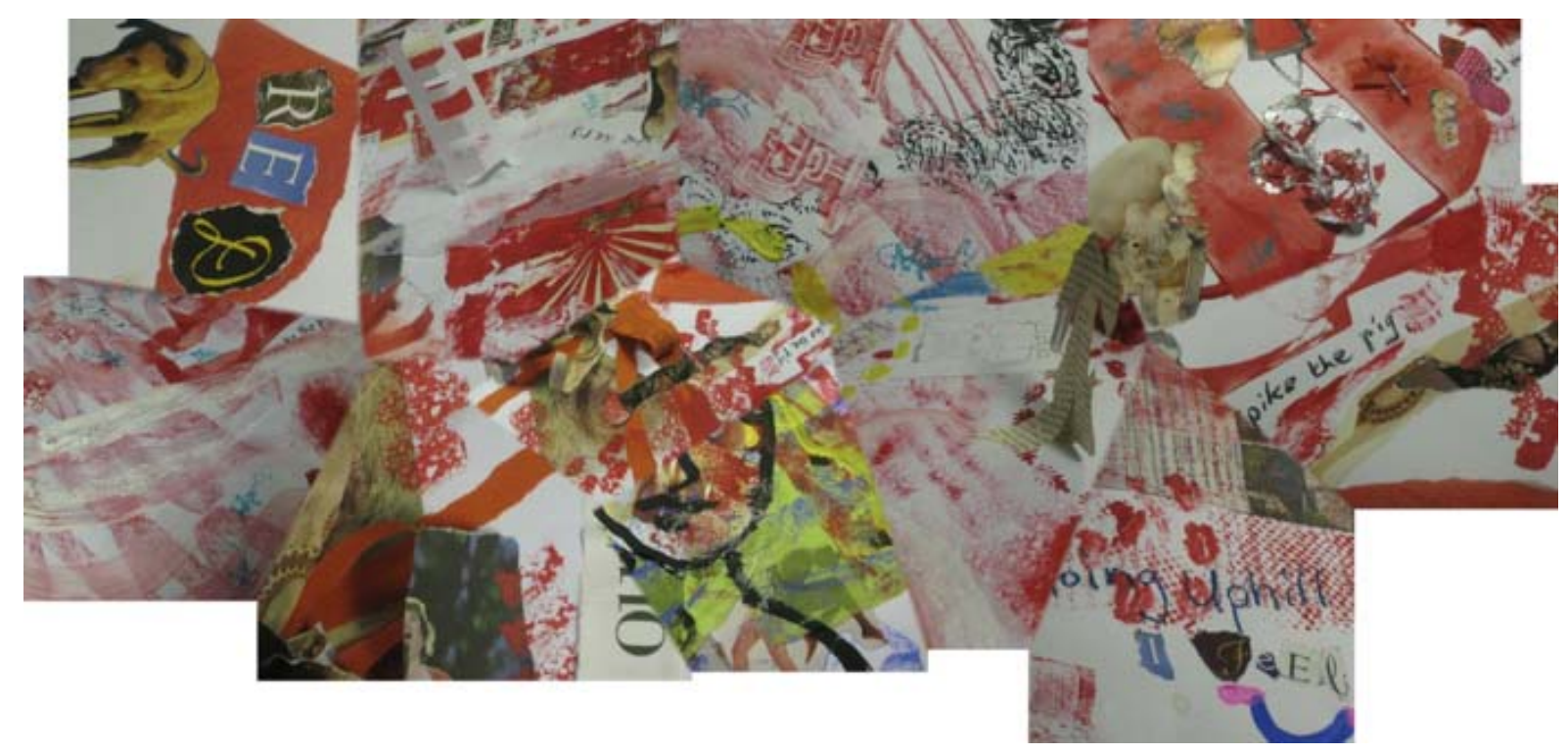




\section{Seeing Red}

We were obsessed with red for weeks afterwards, texting and e-mailing each other about our encounters and entanglements with red in our everyday lives. After the workshop our lives reddenedbetween reading and recommending texts to each other; conducting everyday tasks; experiencing technological breakdowns and undergoing international journeys:

Figure 3. Red montage.

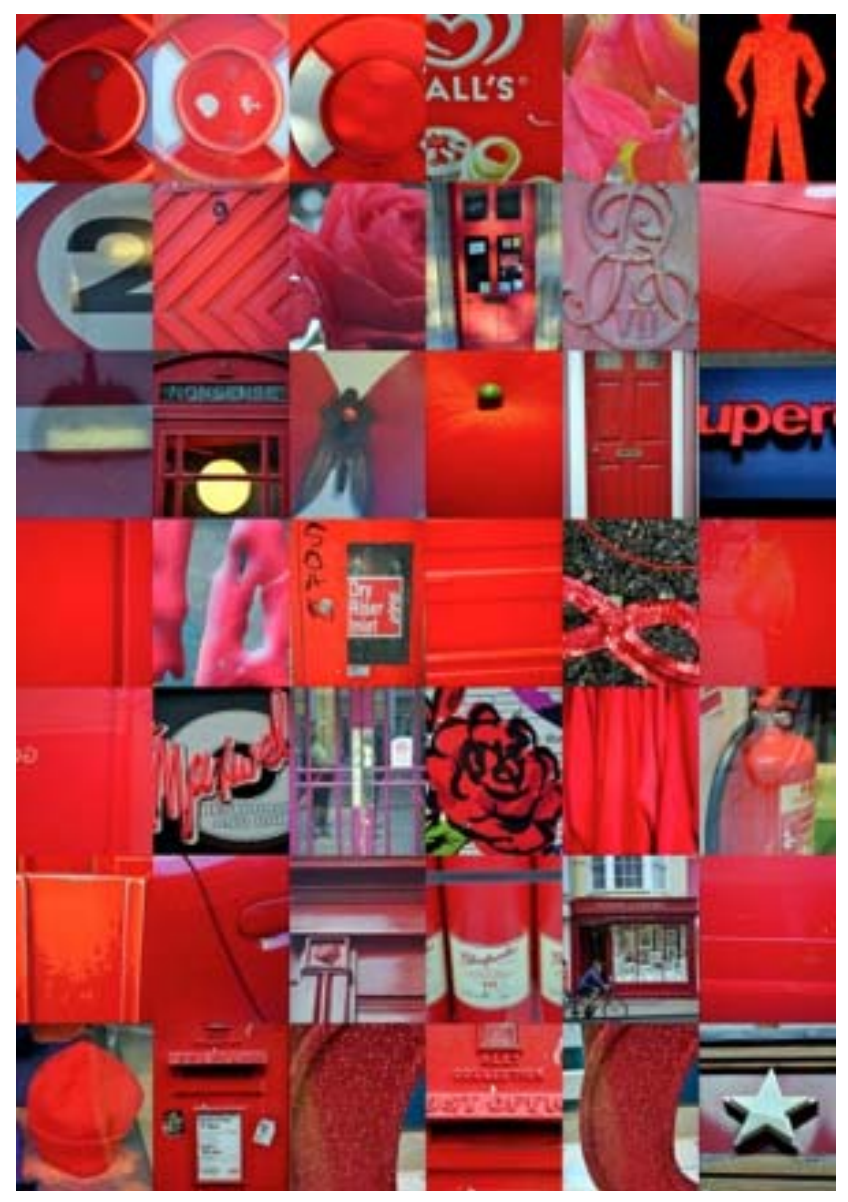

Last week I had to have a particular red hat. I wanted a wool beret and was shocked and horrified at the prices. Now I'm stuck in traffic on the way home from Ammerdown and feeling the need to add a list of reds and choose the right colour for my hat. Where to start with red? It feels like it has caught me unawares and hijacked my senses. Where before it had been blue for years, searching out and collecting photos, beads, and accessories trying to capture a particular shade, now red looms large. 
Figure 4. Marbles in a bowl overlay.

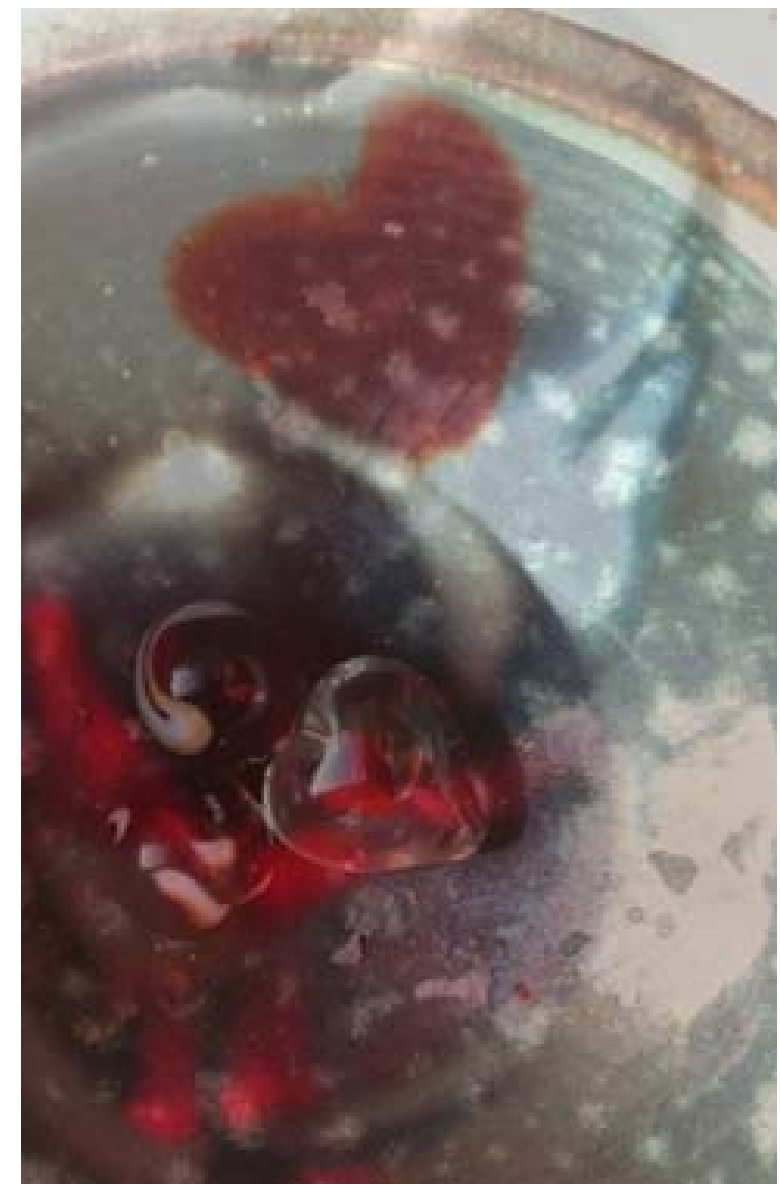

I find myself sorting through bowls of marbles, and buttons, standing in shops chatting to friends with red felted scraps in my hand. You send this to a woman who is spending her half term making red buttons. I find myself unable to stop niggling notions of red; those images are my hauntings from meeting and sharing space with you...

Closing my eyes to the many leaves (red-red, purple-red, yellow-red, orange-red, brown-red, pink-red) that have fallen in the garden that I know will need raking!

Figure 5. Red mirror effects/sky red leaves at Ammerdown mirror effects.

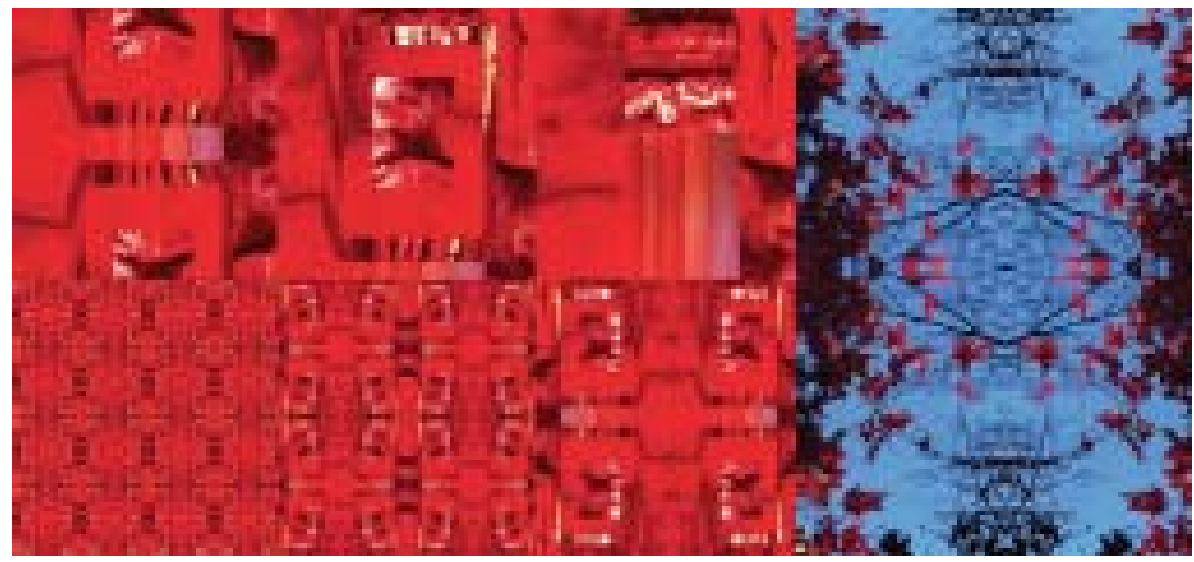


When mulling over the red/ness writing from the weekend at Ammerdown, I was left with a feeling of layering, like the overlapping and positioning of many sheets of filo pastry when making baklava. I find myself mildly obsessed with red, layering, and thresholds. Would be lovely to constructively channel it instead of just craving baklava after reading our email exchanges.

I'm brain-dead and in mid-transit (one night in Paris), sneezing and suffering with a whole-hearted first London chill head cold. Red-nosed. The red lights of Montmartre as my friend walks me back to the hotel. I no longer remember my way home (to any home).

Colours for a red beret: blood, blush, cadmium, cardinal, carmine, crimson, hunting pink, magenta, maroon, rose, ruby, pillar box, scarlet, terracotta, windsor.

Last week was my birthday and I got lots of red presents, including a red book from Sue and a red necklace. You keep reminding me of the protagonist in The Ice Queen by Alice Hoffman [4]. She loses the ability to see red: "Whatever had once been red was now cloudy and pale" ([4], p. 20). But it is not merely sight that is afflicted: "I never mentioned the lack of the colour red, the buzzing under my skin, the clicking in my head" ([4], p. 20). How would it be to lose the colour red? Did we ever ask if anyone was colour blind? What is buzzing beneath our collective skins? Your writing too, the red writing that I intervened in $^{2}$, reminds me of The Girl with Glass Feet by Ali Shaw [5].

Yes, fairytale-esque, magical realism and death...my favourite combinations.

Figure 6. Weaving fairytale threads of impossibility.

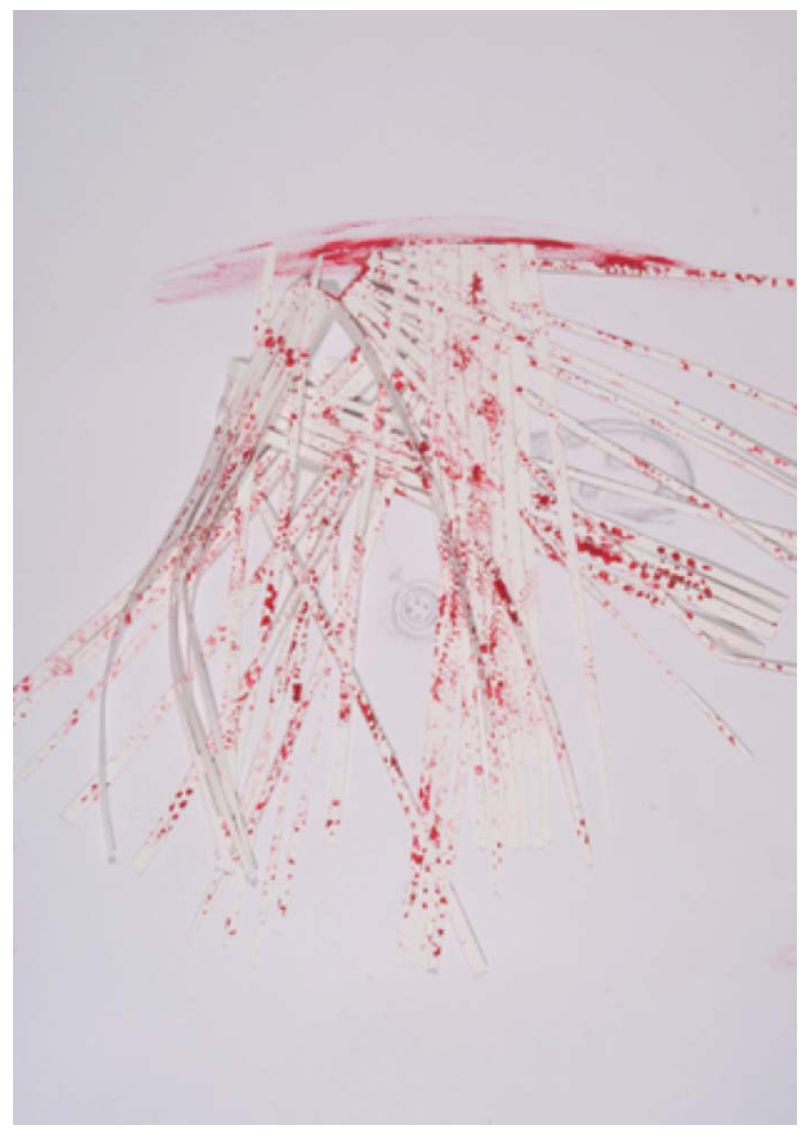

2 A process we used during the Ammerdown weekend where we each 'intervened' in another's writing, e.g., by changing the form or writing the story from a different point of view. See Gannon, Walsh, Byers and Rajiva [6] for extended discussion of textual interventions as a strategy for 'deterritorializing' collective biography. 


\section{Red Runs Riot}

And so our connections around the globe, increasingly fueled by metaphor, fairy tales and material things, went on and on and on... At our workshop, together, we had each written into red, or red had written into us and then we had intervened in each other's red-writings. A woman in a glass dress appeared and ran riot through an autumn forest and through this text that we were creating together. She intervened in our text, became a motif that unfurled like a ribbon in italics through our text. We began wondering and wandering with her, through our own and each other's memories, through the fragments of theory that interceded in our texts. We were implicit in, and witness to, an unravelling that might bring us all undone:

A moment in red. She sits sifting, letting the most immediate conversation settle, slips sideways, focuses on the dark red darning on pink gloves, the cross hatching and patching, the reforming of a hole, covering over but still being present, and the found object at her feet: metal with a hole not perfectly spherical, a little off kilter; the need to hold, press sharp edges into flesh, leave marks; she tries to let go. She wonders/wanders about walking the paths of the glory wood in the glass dress spilling red ribbon and ash, an unravelling. She let herself drift back from the woods to the words, to the ribbons of paths, overlaid now with red enamel lines on vistral re-imaginings, but also being pulled sideways to a memory of red blotching under the skin as the blood settled and mottled, patterned still, not rushing and fluid. Still she couldn't believe, comprehend, lack of movement and her mind kept putting it back in a flicker of eyelid, a breath, because then it wasn't end. It wasn't this, it wasn't cold, clammy mottled flesh of deadweight, of death...It was rosy-hued, it was rose-tinted, blush and bloom of coy seduction, pulse of blood through veins of movement, of life. But the memory of weight brings her back, the memory of blood on her gloved fingertips from behind the skull. She wonders/wanders about walking the paths of the glory wood in the glass dress spilling red ribbon and ash, an unravelling. Kneehigh's ${ }^{3}$ representation of severed feet, stumps of legs with red ribbons falling beautiful and profane poetic, visceral, to cover, re-cover, uncover, weave and knot, interleave-leave. Red-lining of an unworn jacket with red stitching detail on the sleeve and red buttons, softest, inky dark blue needlecord. It had to be that jacket, the one as yet unpaid for, unworn and kept for the right occasion, coffin attire and red socks, soft climbing socks with horizon embroidered across the toe and red darning markers of love and care. She wonders/wanders about walking the paths of the glory wood in the glass dress spilling red ribbon and ash, an unravelling.

3 Kneehigh Theatre Company, http://www.kneehigh.co.uk/ described by the poet Charles Causley as the 'national theatre of Cornwall'. 
Figure 7. The ties that bound us all through red.

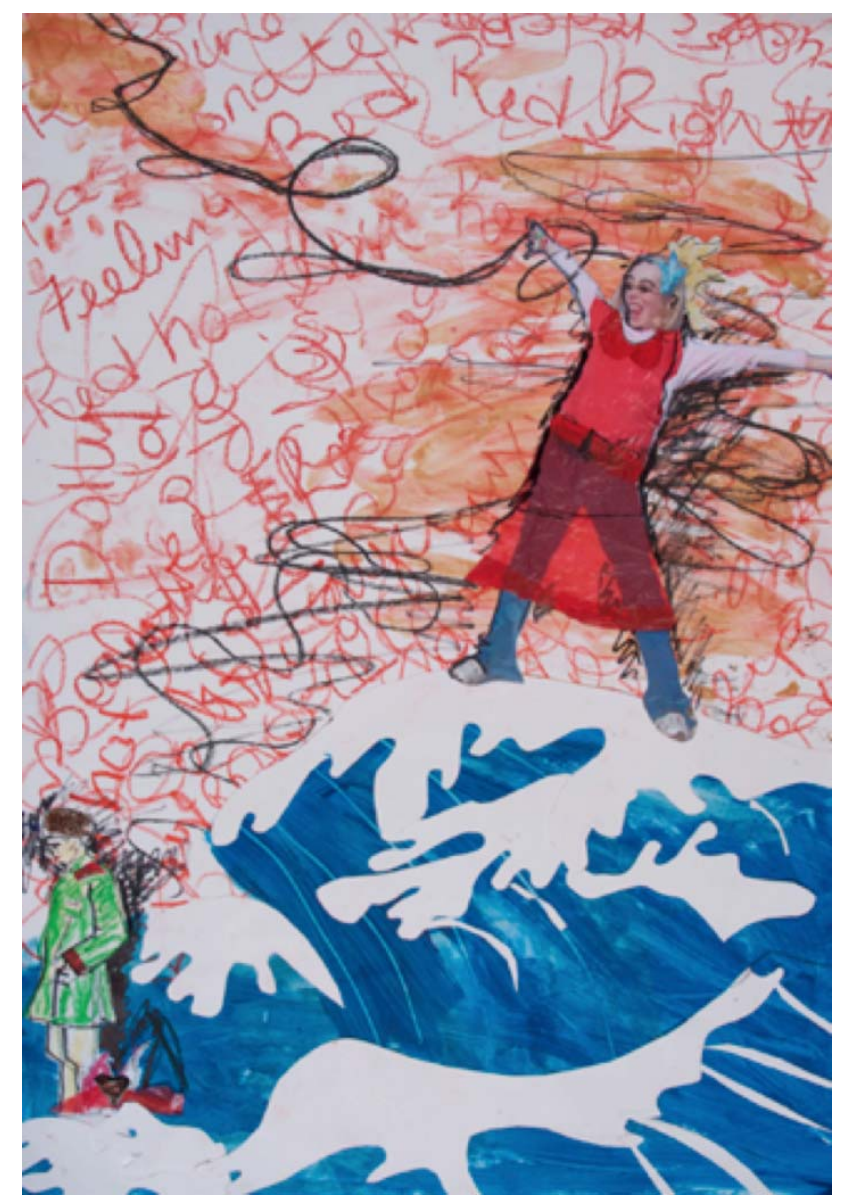

There were three red riding hoods in the room when it all started. The red oozed out of Tessa's button and trickled down across the floor and over to Davina in her red coat, walking through the woods to her grandmother's house. A darker red, a congealed-blood-on-the-fingertips red, poured out from Davina's hands and across the floor. Scarlet, blood, maroon, pillarbox, cadmium, cochineal, plum, cranberry, beetroot, crimson, cardinal and rose. The reds ran riot and intermingled around us. I closed my eyes and caught bright, fleshy-red splodges of yellow-tinged light against the window. When I opened them we were sitting in a pool of red. Entangled. Contaminated. She wonders/wanders about walking the paths of the glory wood in the glass dress spilling red ribbon and ash, an unravelling.

'Perhaps we should be writing about red this weekend' said Jonathan.

Red is already writing all over me.

Here I sit, inscribed in red.

And 'Perhaps we should be writing about red this weekend' said Jonathan.

Perhaps we should.

So much of this red is about threads, ribbons, wool, string, hair, ravellings, unravellings, arteries, veins, flows, lines. I'm reminded of the 'red thread', a metaphor for a line of argument that I understood as a sort of counter logic, a way of pulling through a disparate collection of thoughts or things. Although I heard it first in Germany, it's a version of an oriental metaphor-originally a Chinese but also a Japanese/Korean figure from folktales-representing an invisible red string that the 
gods tie around 'the ankles of those that are destined to meet each other in a certain situation or help each other in a certain way' [7]. They might be lovers but, if they are not, I wonder if they might be us.

I am increasingly interested in how objects can have agency, but since that weekend at Ammerdown, colour also seems to have this quality. Latour's Actor Network Theory (ANT) provides one kind of vocabulary for speaking about the politics of the material world, considering objects/colours and humans as actants or agents [8]. The theory, first developed by Latour, Callon and Law, is often now referred to as 'later ANT inspired analysis' ([8], p. 107) or 'ANT and after' [8,9]. Most recently, Barad develops a theory of "agential realism" where "human and non-human, material and discursive, and natural and cultural factors" are indivisible, where our perceptions of identity, separateness, or distinctiveness result from the particular lines or interpretive "cuts" we make rather than any essential or inherent properties of things, including human subjects ([10], p. 26). We are entangled in the matter of the world, and it is in this entanglement, in the volatile spaces of these "intra-actions" that agency and identity emerge [10-12].

If we turn to materiality, and consider colour as matter, and as therefore already in and of the matter of the world, then its agency is integral to its materiality. The carmine red in Turner's paintbox, which faded almost as soon as he used it, "is really made of blood" ([13], p. 126). This is not a metaphor. Would Turner be a painter if not for the blood squeezed from the cochineal bug, after its short life gorging on prickly pear on the other side of the world? Red was treasured by the Incas, the Aztecs, the Spaniards; was used for "the robes of kings and cardinals, on the lips of screen goddesses, on the camel bags of nomads and on the canvases of great artists. And if it disappeared the next day many of its users didn't care, because on the day it is fresh, carmine - cochineal or crimson; it has many names - is one of the reddest dyes that the natural world has produced" ([13], p. 126). Turner's paintbox also contained many natural red ochres from earth, and at least twelve types of madder, a red derived from the roots of the rubia tree; red lead, a colour made from heating white lead popular with Persian miniaturists; and cinnabar or vermilion, a red made by combining mercury and burnt sulphur (or the merging of the blood of an elephant and a dragon according to Pliny) ([13], pp. 148-49). Turner emerges as a painter in the entanglements of this matter of the earth, of imagination, of tools, of arm and eye, assembled in the social economy that recognises art in the blood of a beetle smeared on canvas.

Another language of the agency of objects is magical realism, whereby the malevolent pins and needles fly out of the sewing box and embroider all the people in the room together, weaving red threads through their eyes and feet. In the literatures of magical realities, objects, humans and the living world alike all have agencies and the borderlines between different kinds of reality are routinely blurred and crossed [14]. She wonders/wanders about walking the paths of the glory wood in the glass dress spilling red ribbon and ash, an unravelling... 
Figure 8. Evocation and shrine for a ritual object.

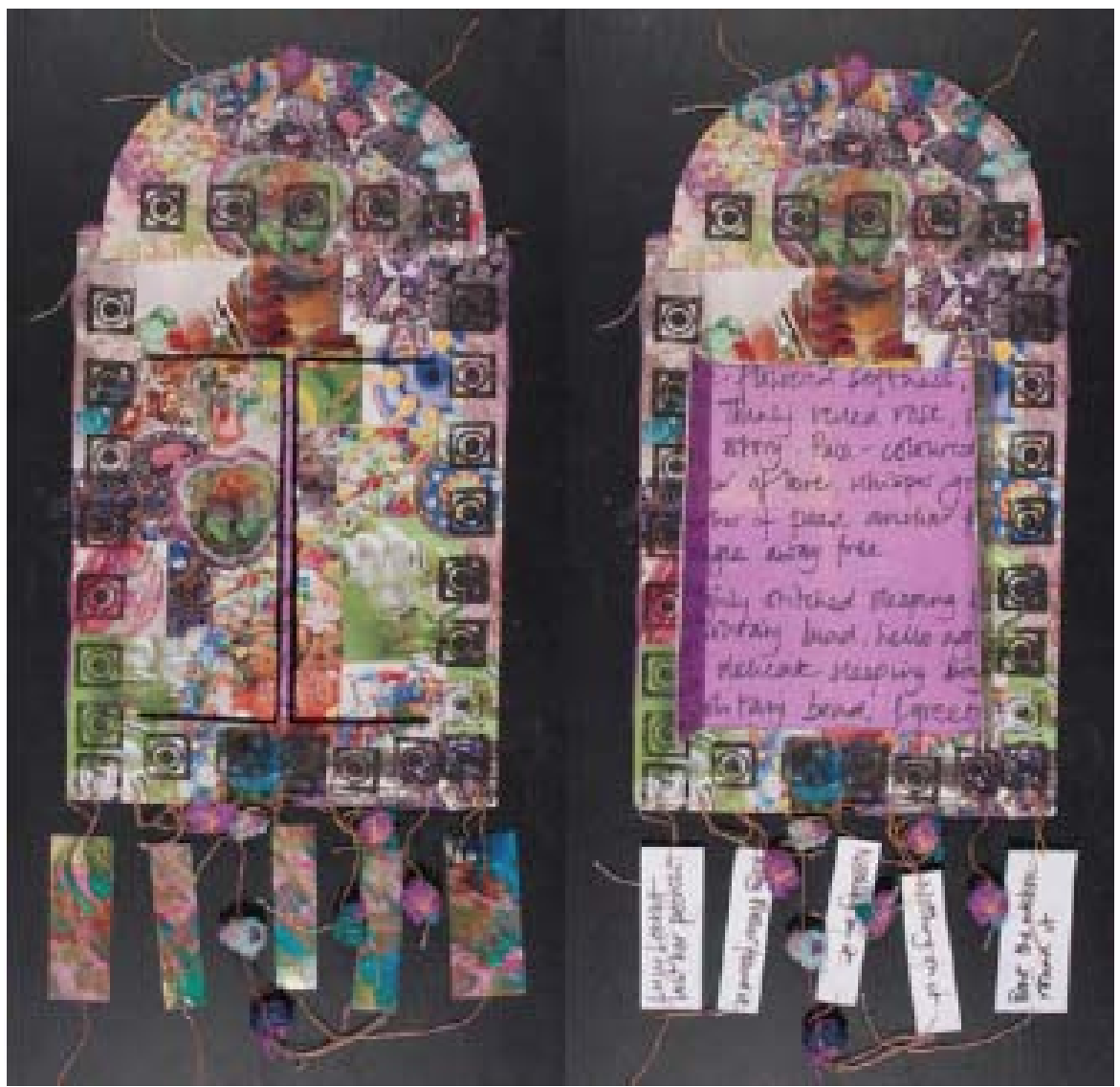

A sewing box and a red button: Thinking objects through mutable mobiles and agential reality [10]. As Johnson points out, the nature of objects is to change, they "do not necessarily remain the same as they move across contexts and through time, rather objects can be "mutable mobiles"” ([8], p. 106). She elaborates how objects "resist closure, oscillating between various understandings and definitions even within the same context and time" ([8], p. 106). Then there is "thing-power", in Bennett's words, signalling "the strange ability of ordinary, man-made items to exceed their status as objects and to manifest traces of independence or aliveness" ([15], p. xvi). The locus of agency in thing-power, she says, is always in a "human-nonhuman working group", in vitality as a "function of the tendency of matter to conglomerate or form heterogenous groupings" where agency emerges and moves through assemblage rather than separation ([15], p. xvii). Objects gather together with each other and with other matter and bodies that become new things together in their movements.

Thinking about the sewing boxes, the objects and artefacts inside the box will have different meanings and uses for different people. They will bring those people into new relations. While physicists, like Barad [10,11] will meet the universe halfway, novelists like Shaw [5] will entangle us all in multiple universes of the imagination.

Every object is inherently inconsistent and subject to change. This almost sounds like the physics of magical realism. If I ran out of pins hemming a dress, I could substitute a needle and then use the same needle later to remove a splinter. What if that splinter turned to gold? She wonders/wanders about walking the paths of the glory wood in the glass dress spilling red ribbon and ash, an unravelling... Is it the same needle when I hem a dress as when I mend a curtain? Was the steel recycled in an earlier 
life as part of a car? The objects in my sewing boxes will have different narratives and uses depending upon who opens the box. Will a wind blowing from the west make a difference to what we find when we open the box I wonder? She wonders/wanders about walking the paths of the glory wood in the glass dress spilling red ribbon and ash, an unravelling...

Figure 9. Red collage section.

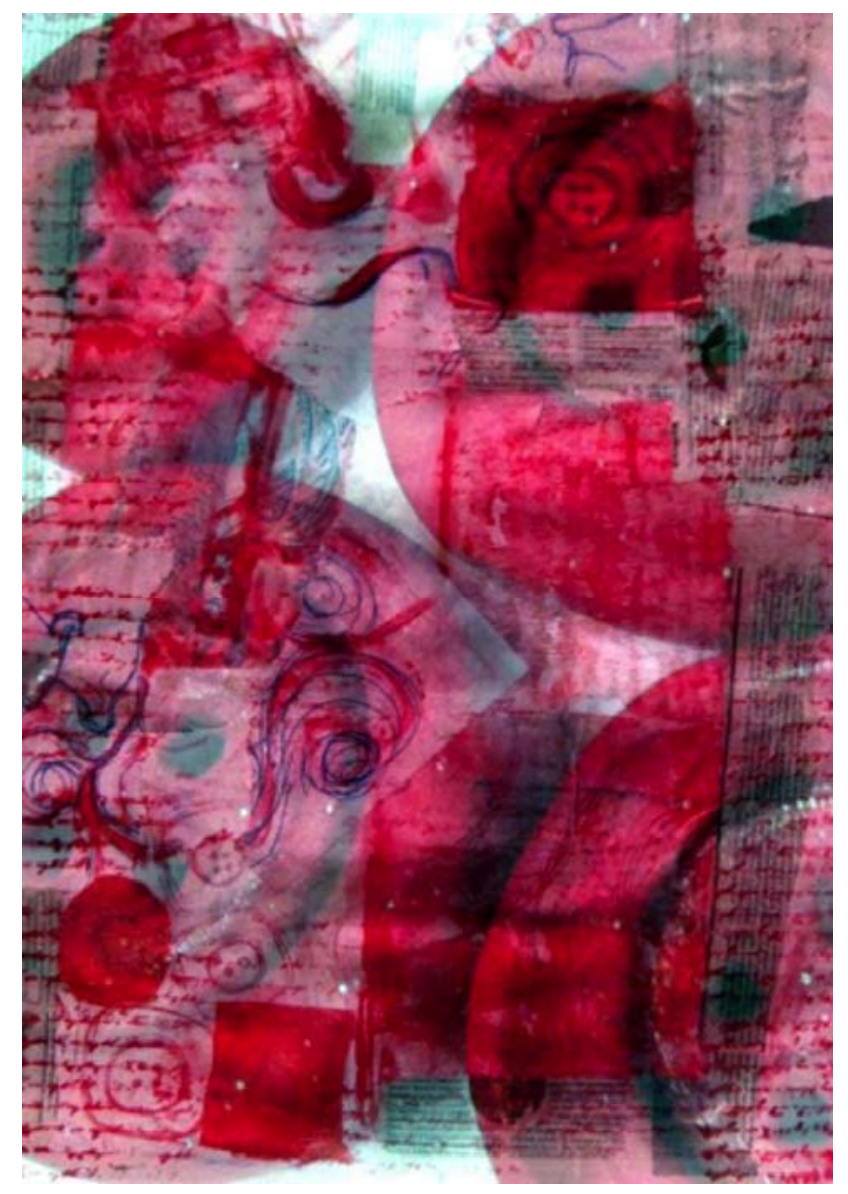

In the button box in our French house in Montjaux, there is a red button similar to the one that I have at home. I identified my button as coming from Mum's original button box. Now I think about it, it used to be on a red wool coat. I forgot that the buttons came in two sizes until I opened the button box at Montjaux. There were the larger ones down the front, and a smaller version on the pockets and cuffs. Dad always liked Mum's coat. The French buttons are in an old Turkish delight box. I don't remember there being any buttons in the Montjaux sewing box last time I looked. I can see Dad picking out the red buttons and handling them, thinking about Mum's red coat and then bringing the box to France. I have been wearing the button around my neck.

According to the principles of agential realism, agency is a matter of intra-acting; it is an enactment, not something someone or something has. Agency cannot be selected as an attribute of subjects or objects (as they do not pre-exist as such) [10]. Thing-power emerges and moves through humannonhuman assemblages [15]. Magical realism, however, is dependent upon a seamless shifting between different realities, whereby magical tales and actual stories inhabit the same texts, cheek by jowl [16]. She wonders/wanders about walking the paths of the glory wood in the glass dress spilling red ribbon and ash, an unravelling... 
I tie the button around my neck. It will be a different colour back in the box; it is bright and reflective when I wear it. Someone could sew it onto a cushion, a dress, or I could make it into a ring. Where will it go next? Is it oscillating between different understandings as I write? Or is it an actant that is intra-acting within all these ideas, with me, with future possibilities I cannot see, and more? I had thought it was a red button that used to belong to my Mum. By holding the buttons I feel very close to Mum and her red coat. The button has an impact on me, it influences me, and it creates me as part of a mother-daughter assemblage with the object.

It all started with a button. She wonders/wanders about walking the paths of the glory wood in the glass dress spilling red ribbon and ash, an unravelling... There was an agential realism to the amount that matter mattered and colour counted and a magical realism to the fairy tale atmosphere of our weekend together, in a country estate shaded by a tree grown from a thorn brought to Glastonbury by Joseph of Arimathea, surrounded by a glory wood, the reciprocity born of our writing into a materiality that was writing, colouring and, indeed, obsessing us.

I have been tormented by buttons

My fingers played with the ridges and holes

I longed to play with polymer clay

Forming, manipulating, creating

My own representation

Clumsy, rough things

Finger prints, imperfect, my own representation

Totems to Mum and her red coat.

She wonders/wanders about walking

the paths of the glory wood in the glass dress

spilling red ribbon and ash, an unravelling...

Stories of memories, tinged with tones of red.

A spectrum of red from pink to maroon.

These stories weave degrees of redness

on, in, around and through objects

(both inert and living) and subjects.

A coming to life, through the colour red.

A remembering of life with the colour red.

Memories in life hinged on this colour.

Reflecting boyhood around the colour of red.

She wonders/wanders about walking

the paths of the glory wood in the glass dress

spilling red ribbon and ash, an unravelling...

I roamed around my i-Pad searching out red. Red was under scrutiny. I started, as is often the case, in the British Library and clicked on illustrated manuscripts... Surely there would be something red? Coral, crimson, cardinal, carmine? And there, first page, from sixth century Spain, was Silos Apocalypse [17], introduced by a seven-headed bright red serpent, accompanied by angels of death 
with blackened wings, all on an orange background. The fires of hell perhaps? I made my own serpent with 'brushes' on my i-Pad. There was no room for any angels of death... Only an angel from Mars on a separate page. Red and orange. The colours of blood and fruit, the colour of fires and Mars, the colours of hell. This was colour-full research.

Figure 10. Identity.

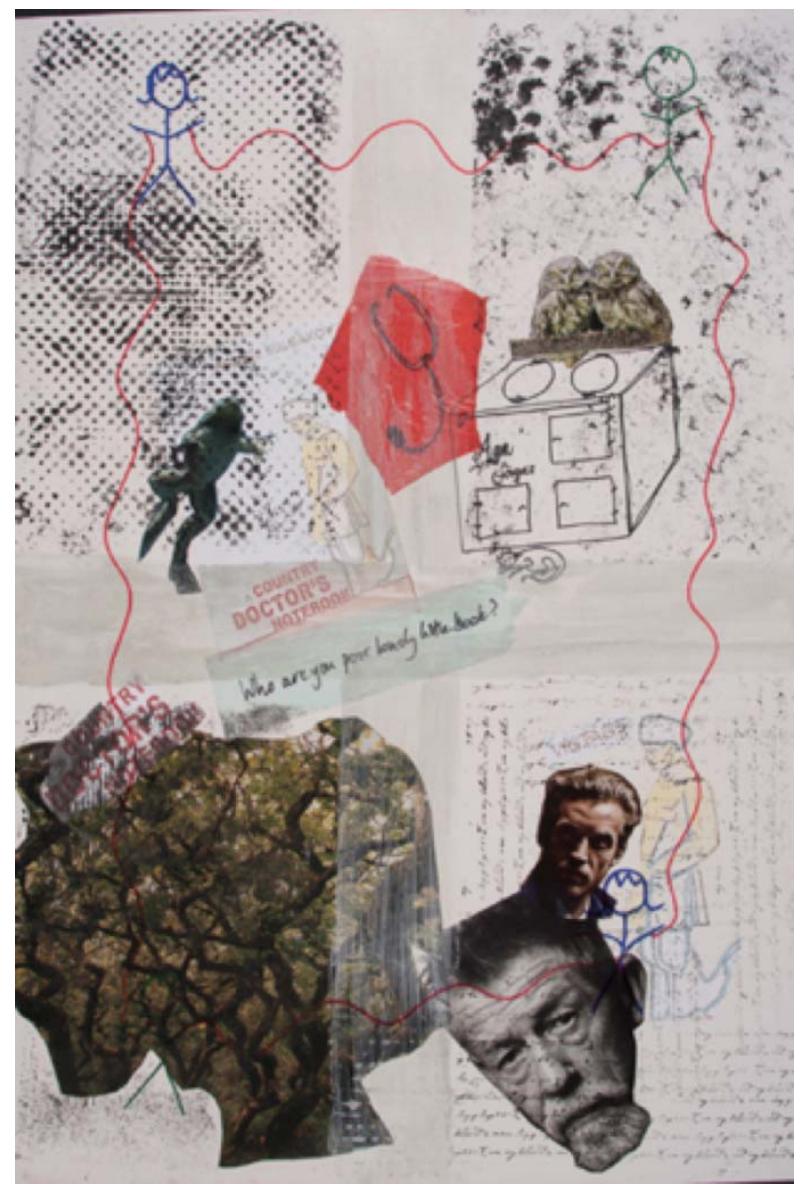

I have just misread our keywords: I read 'genital and magical realisms'. It was almost as if, like Cixous ([18], p. 67), we could hear the writing writing us...

Figure 11. Ammerdown Forest Autumn Trees.

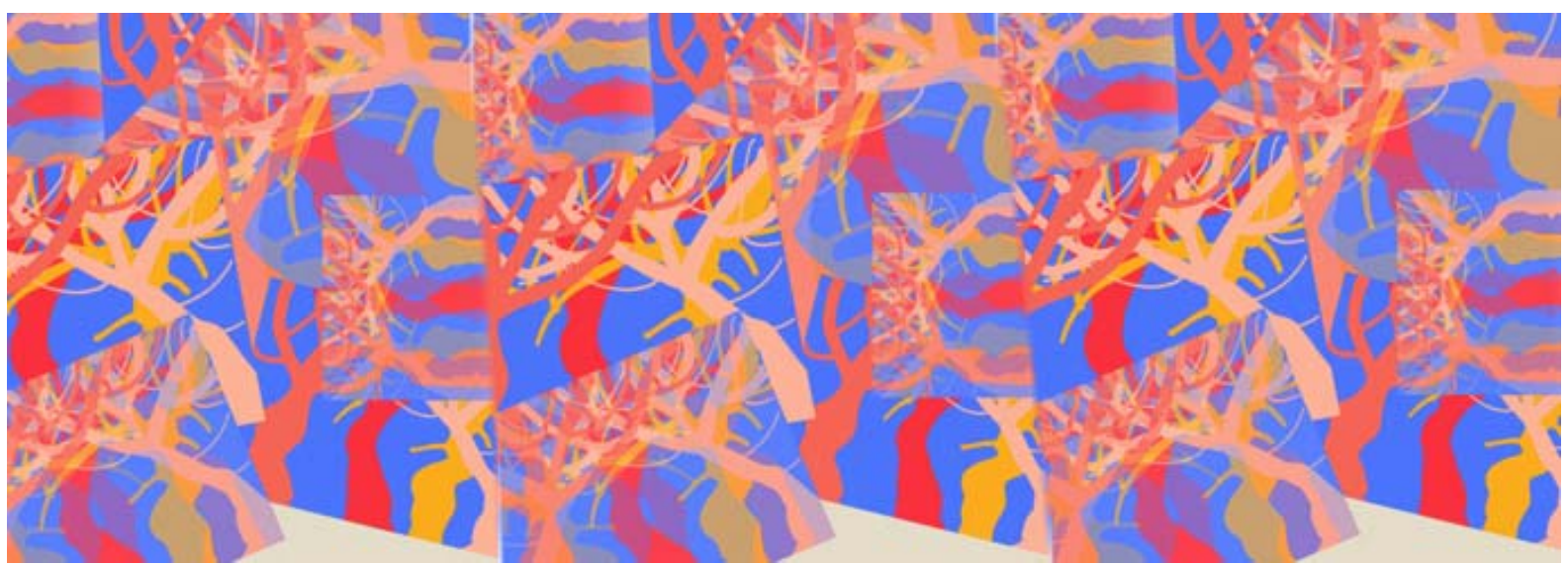


Gathering up the three red riding hoods, the ice queen, the girl with the glass feet and the angel from Mars they wondered and wandered about, walking the paths of the glory wood that surrounded them. Although ecumenical, Ammerdown was a Roman Catholic retreat centre in origin, riven with biblical intertextualities and evoking dreams and images of saints and sacred hearts. All this talk of angels, albeit from Mars, not to mention that the walls of the workshop were by now running with the colour red, was somehow in keeping with their surroundings. Collective biography groups often come together in unfamiliar, or at least not their usual surroundings [1] to meet and write and this weekend workshop, dominated as it was by red writing, had been no exception. Gradually the surroundings crept into the writing and the writing crept, like the deep red ivy on the stone walls, into the surroundings.

She wonders/wanders about walking the paths of the glory wood in the glass dress spilling red ribbon and ash, an unravelling...

Figure 12. Scribble division and reflecting aggregate.

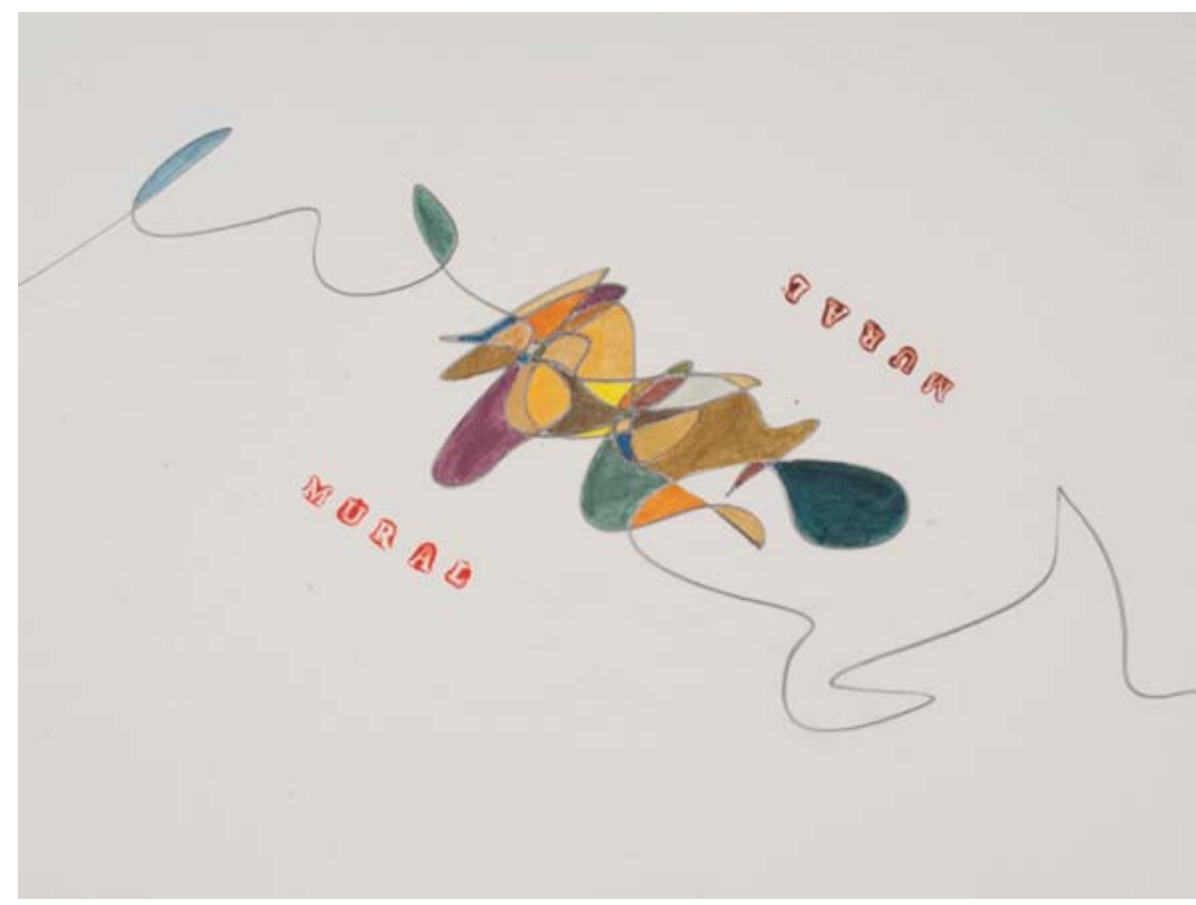

\section{Interrupting Red}

In this section of our paper we turn to our childhood memories of red and the textual interruptions that were part of our workshop processes. If a text begins as 'mine', if the memory is mine alone, how can we find the points of connection that 'matter' amongst us, between us, across us? How can we push from a sense of ourselves as discrete and willful individuals separate from each other and the world towards entanglements of being where childhood memories might be understood as affectively potent "blocks of becoming" that open "lines of flight" and demand inventiveness, and where our writing together and into each other's texts "strives to capture a shift in thought that is happening to the writer and which the writer is inviting" ([19], p. 14). There are at least two writers for most of the texts of childhood memories of red in this section, an original author and an intervening author who worked the text in a different direction-bringing in what they know of language and childhood, importing details from their own contiguous memories to write poetry, or to write from a different point of view, 
or to bring the body in, or to change the voice. In this textual intervention, they might thus begin to open up the narrative of memory to more than this and more than me, and move towards a sense of self as an assemblage. Beyond any particular authors were the particular assemblage of writers, readers and listeners in a particular place and time who also shaped each text and further worked through the assembling of this paper. The process notes that begin this section hint at the affective potency and ambivalence of our strategies of textual intervention in red:

Mike took my writing about the rosette and cut it back to form it into a poem. I enjoyed the element of not knowing: the awareness that he had spent time with my writing, giving it attention, but not knowing what he was up to over my left shoulder; before, opposite me across the room, beginning to speak. I thought about it as a kind of witnessing. Hearing 'my' story emerge in Mike's voice as something else, someone else, was both tricky and a pleasure. I didn't 'like' some of the re-framing, wanted to change it back; but have since liked the poem's new sharpness.

I amended Jane's, writing more of the body and affects into it. At first I felt stuck because Jane had already brought the reader into the affects and sensations of the scene, but I found moments where I asked 'what might be happening there? What might she be looking at? Noticing of Wendy or in herself? And then it became fun, seeing the zit on Wendy's face. A part of me had the sense of being Jane at that point - Jane as adult, now, with her sense of mischief - and what she might enjoy; I thought I could hear her voice.

Wendy ran up behind her in the playground and pushed her roughly into the wall of the wooden hut. She was a big girl Wendy Mott. Huge. Bigger than the others. She felt the urge to pee. Your Mum's a red innit?'

'Wor you mean?'

'Standin fer the council, your Mum is, she's a red, intshe?'

Wendy leant her face close to hers, so close she could see her spit.

'Bloody outsiders, comin down from London, standin fer the council. My dad says she's a Jew an all, but I put him right on that I 'splained she can't be a Jew, cos you're in the Brownies...'

'My mother is standing as an independent councillor and we moved here from London when I was five', Jane explained, pulling herself up to her full height. She came up to Wendy's chin, her eyes level with the buds of Wendy's newly erupting breasts...

'My dad's on the council, he's a Tory. Tory born and bred Sussex born and bred...never even been ta London...'

'Garn, wodja mean ee's never been ta London, it's only up the road'

She saw that Wendy had a zit just below the corner of her mouth, about to pop. A red zit, a pox, a bloody bursting.

'Bloody long road tho innit... and what's at the end of it... bunch of Jews and reds... and all sorts; bunch of drugtaking villains that's wo my dad finks... he really knows this area my dad, knows all the people, he's a local...everybody knows im...everybody knows Mott's is the best butchers...Wots your dad do anyway? S'your dad a red 'n all?'

She could, if she'd wanted, reach up and squeeze the zit between her fingers; and felt, just then, like she could do it. Or punch her. Or grab her tits. Wendy would yelp. But she didn't. Couldn't.

'My dad, well my dad, my dad works in London, in an office, goes up every day on the train... 
'London, eh, an office in London. What's wrong with the offices in Chichester then, eh? S'he a red an' all is ee, your dad?'

Wendy's voice rose with her excitement, her voice piercing her, hurting her ears.

'Wot's wrong with local, if he likes London so much why doesn't your dad live there, along with all them other reds and Jews?... Course Jews can't be in the Brownies...think of yer Brownie promise girl...'I promise to do my best, to do my duty to God an' the Queen, to help other people every day, especially those at home...' Jews don't believe in Jesus, or the Queen, my dad says, so Jews can't be in the Brownies...can they?'

Jane opened her mouth to argue, but no words came out, her mouth had suddenly filled up with gobules of fear and spit, one of which dribbled down her chin...

In bed

white metallic blinds

cut the posters with morning light.

Navy blue lines of Cardiff City, then

Orient, Arsenal, Liverpool, Sunderland

and more

cut from the magazine.

His head

tilted at the cork pin board

cut through

team colours, rosettes and Paddington

(he didn't tell his friends).

The rosette

red pillar box Georgie Best.

His name -

Georgie (for girls) - never a real favourite.

City Blues,

now there's a thing, secretly preferring, with black and white

clarity, the sliding goal that won

the cup

from Gornik Zabre.

His hand

supporting him,

he leaned and pulled the red

genius George from his drawing pin.

Lying back for a moment,

Looked at handsome George for the last time

and took his place in the new day. 
Figure 13. The materiality of drawing.

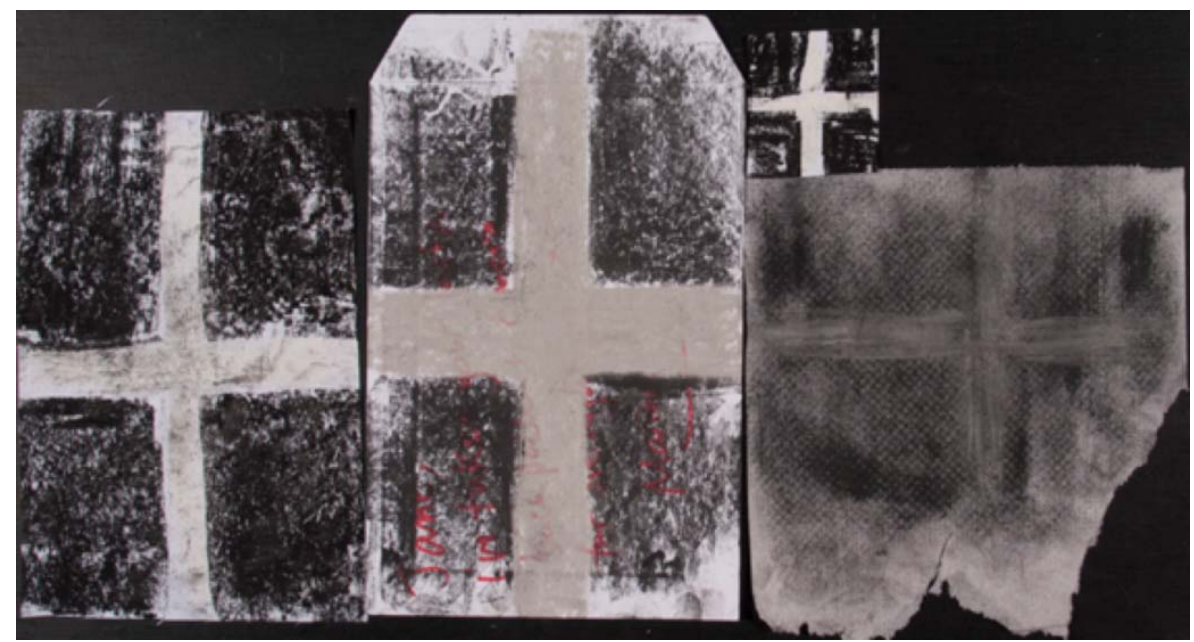

Reader, close your eyes. Can you smell gardenia soap on your mother's skin, or the Maja perfume that she dabs at her wrist, in the fold of her elbow and on your arm if you are hovering close at the right time? Can you still see the little red and black box with the Spanish dancer on her dressing table, by the cut glass bottles that you are sometimes allowed to touch? Can you feel the talc drifting up your nose when you are bathed and clean and dressed and snuggling as close as you can to her? Do you feel her hands on your still damp hair, the brisk line the comb makes on your scalp, her hands on your shoulders holding you back so she can see if it is straight, and her fingers pressing down the wayward drifts ready for the photo? Do you remember pushing your face into her neck, your little animal snuffles as you burrow into her smell and into her skin, just above the thick seams of her bodice? And do you remember how she pulls you away, slightly, puts her hand on your shoulder to turn you to the front? Probably you would press your head back into her but she would hold you away a little, fix you in place with her right hand, ready for the photo. Do you remember the new baby on her knee, taking most of the space? His fingers wrap around hers, his eyes are on hers, and hers are on him. You know he can't see her properly yet. He can't see the colour of her frock, that it is red, a particular exact dark red, that you later learn to call crimson. A colour that is. More often, for other ladies, a Spanish dancer on a perfume box, a black haired aunt on the other side, and for you, in the frock that she has made for your doll from the offcuts. Close your eyes as you press your face into the doll. Her frock feels like your mother's on your skin. You know, don't you, that there must have been a photo with you in it too, but the one you have has just your mother and the baby. You can't see them properly now in this little black and white photograph, and her dress is grey, her dressing table a monochrome collection of shadows. But, with your eyes closed, you know that colour, that exact deep crimson of the particular shape she makes amongst the greys, and you remember its velvety feel against your cheek as you wrap your arms around her waist and press your body into hers.

Hearing Susanne read her version of my text opened up memories, history was rewritten, I was forced to expand my version. Were you there? How could you know? How could I have forgotten so much? It was like viewing what happened by gazing at it reflected in my mother's dressing table mirror. Another and parallel reality.

She strutted across the flagstone backyard to throw the scraps to the geese. 'Keep back', she told him, 'they could break your leg!' A little scared he sheltered in her lee as she brushed past the drying 
undies pegged with the gypsy-whittled wood. Nana always bought something when they came, even if she swore at them for coming alone with just the lucky heather-of course it held no luck, and she bought it nevertheless.

The red geraniums on the scullery windowsill glowed behind him when he turned to the noise of the cat spilling an outdoor plant pot. 'Nana', he said, 'why can't we go in the cellar?' It'd been playing on his mind for a while, with overheard strands of confusing worlds. The words were mixed like a summer pudding - the dark oozing maroon seeping tantalisingly through the white bread, all unseen until the brick weight was removed and the basin turned onto the waiting plate. And then the juices, bitter tastes of late summer berries against the chipped crockery. The words whispered of the dangerous unknown. 'Hanging', 'spiked', 'scrubbing down', 'the slab', 'hooked'. The bucket and the sharp-spiked brush, the sleeves rolled to the shoulders and the washing down with carbolic. The smel-never quite quelled by the pink soap. What was it all about, he wondered. How did it fit into this wonderful 'Nana-world'?

She threw the bucket contents over the gate and turned on him.

'Why can't we?' he asked again. 'You don't want to see that' she said, 'not for little ones.'

'Where's the pigs?' he asked, remembering the squeals and a sneaked peak around the shed door. He recalled the splashing sounds against the bucket— the drumming on enamel.

'Black pudding', she said.

And then he remembered how mum had told him how she'd hid in the cellar when the planes had come up the valley shooting their guns, and Beryl had been hit, the red blood seeping through her white blouse.

We were provoked into a space of writing otherwise and beyond the thresholds of ourselves and of the present moment, into a productive liminality, "a fractal chaos, a storehouse of possibilities" where "new forms and structures" might emerge ([20], p. 39).

A large home exhibition, they stand agitated and fidgeting, trying too nonchalantly not to be caught into the game of ultimate class and power, hierarchy and celebrity beyond measure. They are primed, told how to behave, what to say. Will anyone transgress, speak before being spoken to or make an utterance that is unexpected, unplanned?

Bodyguards, black suited men ripple outwards. She doesn't want to be affected, wants not to care if he speaks to her or not, wants it not to matter but in knowing how much she wants it not to matter she knows that it does; that centuries of serfdom and fiefdom cannot be ignored, rewritten in this moment—even by an artist.

Filled with a crowd. Big bodies and voices crammed into narrow alleys and stands. She feels herself slipping, growing translucent, transparent, wraith-like, slipping between the bodies, slipping into the bodies, inhabiting the voices.

Unnoticed amidst the adults pursuits unnoticed the subtle changes occurring between conversations and pauses. Bodies suddenly pressing against another or letting a touch linger or tracing a finger down the curve of a spine, the arc of a well-developed calf muscle; looks of shock, amusement, anger, disgust.

She honed in to a model of a house, encased in a glass box. The miniature doors, synthetic trees draw her in, enraptured by this protected world. She melts through the glass into the house, running between the rooms, up and down the stairs and constantly finding new rooms and doors, staircases that change, configurations that shift and it is huge and endless and a joy getting lost. 
Her glance moves sideways to the tallest wall amongst the ivy an out of proportion ladybird has been planted in the décor. It stretches, flexing its wings and then whirring them so they sound like the sound of r's rolling in the mouth, the sound of Rumpelstiltskin's spinning wheel as he worked all night spinning flax into gold - endless tasks of impossibility; a rhythmic whirring. This eccentric detail calls to her reminding her of cold nights tucked up in woollen blankets having stories rewoven, re-enlivened with sounds and colour and red. The red dressing gown with a hood hanging on the back of the bedroom door- "'hush, hush whisper who dares, Christopher Robin is saying his prayers..."

Seeing and hearing the unexpected insect brings out the strangest desire in her; the only childlike thing in a grown up place. Through her, back through layers of time and place, skittering through her mind threads and threads- some loose, some joined, some tangled and knotted. First she barely allows herself the fantasy; to have it and hold it clasped in her hand - this skein of wool, thread, flax, gold, blood, guts, smooth, rough, fibrous, sleek, "to say it is mine, it is me".

Figure 14. The paper is moss.

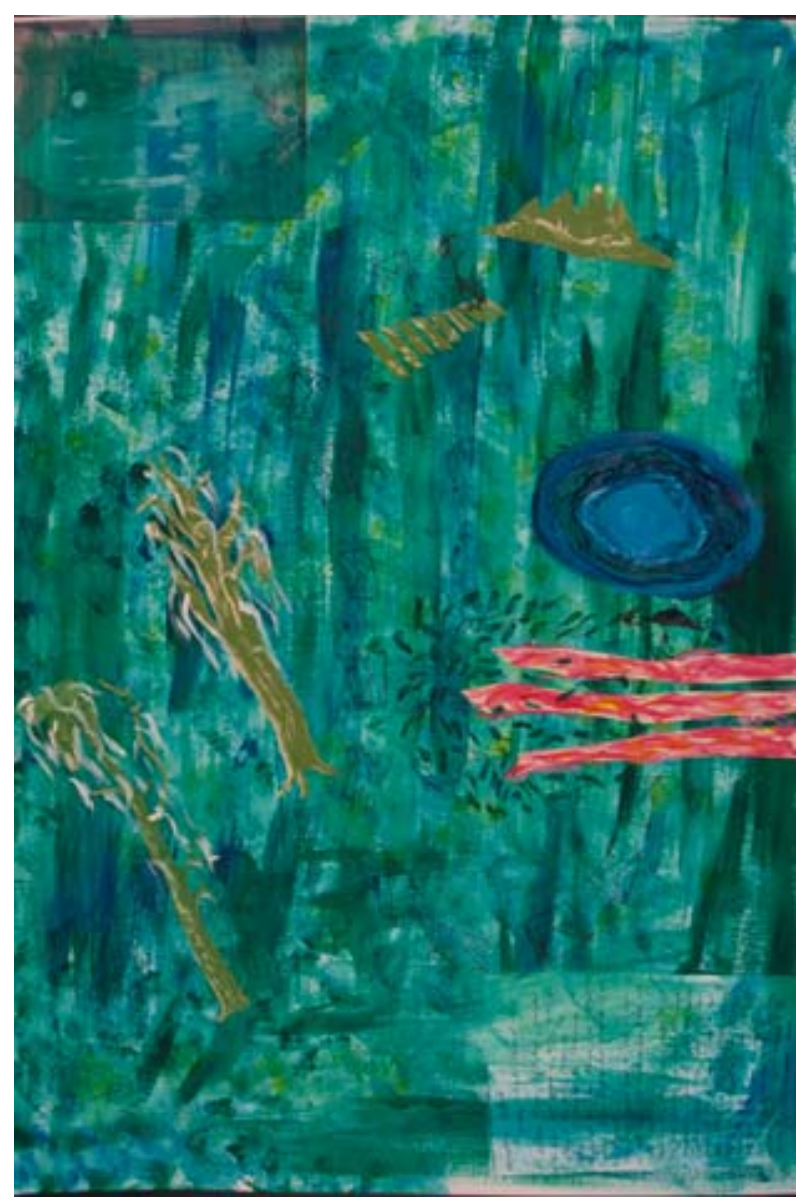

She was a bright girl. The stories swirled around the playground, dancing and playing as they escaped from her lips. They ebbed and flowed, pop stars tangled in the skeins, threads tied themselves around the audience, plucking at their heart strings. The words swelled and absorbed energy and time sometimes exploding, a Norse God helped them on their way.

The energy for stories changed and developed over time, hidden between paper sheets and mathematical formulae. It seeped and crept into tubes of paint, washed in thin layers across the paper. 
It clung to brushes, a painting kit. It escaped Swirling round the girl, as she played with new art equipment and paper.

One of its favourite places was the art department in Sissons and Parker. It danced up the wooden staircase, cast shadows on the slabs of colour, roaring with laughter at the sheer size and volume of the materials available to play with.

The girl seemed to become blind; she ignored the call of the colours. Her mother's power overwhelmed the need of the stories, which became drained as the girl recited the names of different white paints in her mind.

The mother's energy grappled with its own stories of red, fallen women, red shoes, ankle brackets, danger. The girl inhibited by fear that emanated from her mother chose blue, it calmed and soothed and restrained the energy which might overwhelm her if given loose rein.

Finally the energy broke through, the stories swirled and danced again, vivacious and energetic. They represented the girl's life force, Estée Lauder red lipstick became her new badge of choice.

\section{Conclusions}

What are we doing here? We have created a voluptuousness of writing as our inquiry into red. Between us, scouring our memories, we have written ourselves into a saturation of red buttons, ribbons, dresses, politics, footballers and lipsticks, layered with photographs and other images of angels, trees, leaves, buildings and statues, in what Geertz [21] might call a thickening of our description, or, dare we say, a "reddening" of our description. This work represents what Springgay and her colleagues [3] in their advocacy for a/r/tography as method would call a "reverberation and excess" of obsessive red writings and image making. There is congruence of method with our madness. Like Deleuze ([22], p. 14) we have a fascination with the ways that writing (and other expressive art forms, like image-making) "flies off in all directions and at the same time closes right up on itself like an egg". Like Pink $[23,24]$ we crave academic language that speaks in both discursive and visual forms and acknowledges the space, and lack of translation, between modalities. Like Roswell [25], we are interested in the sensory loadings of objects and of matter and how these provoke new relations with ourselves and with each other. We are interested in the agency of objects and of art, in "thinglyness" and in creative (and political) processes of writing and of making [26].

We set down layer after layer of our work: writings engorged by our memories of red, photographs and other visual images suffused in different red shades, layering them all into each other.

This "doubling" of words and art "resists transparent rereadings and rewritings of experience, preferring complexities and the process of appreciating complex meaning making"; in qualitative research, it generates new methodologies that acknowledge processes as well as products of research ([3], p. 900). But our text is not merely a doubling of text and word, combining or trebling as it also does all manner of material things, and then there is the matter of red that came to infuse our inquiry. Perhaps like Hoffman's ice queen we are "just more sensitive to colour than most people" ([4], p. 210). And, through this process, perhaps each of us can now say that "in our house every room is red, each a different shade: ruby, scarlet, cherry. Some people think it's all the same, but the tones couldn't be more different, so much so as black from white" ([4], pp. 210-11). 
Indeed, when we began to paint together in reds the tone(s) of our voices were radically different, despite painting into and out of each other's drawing spaces, just as we had intervened in each other's red writings. Unexpected figures emerged, like the woman who wonders and wanders about walking the paths of the glory wood in the glass dress spilling red ribbon and ash, an unravelling... We followed her red ribbons of glory and of ash through the forests of Ammerdown in autumn, through our imaginations and memories inside that room in the country estate, and afterwards, when we too had dispersed - or perhaps fallen away like the autumn leaves - to our own home places.

This paper embodies more than an arts-informed method of research, whilst equally it is not art-as-research: it is more research text as artefact. It encompasses a/r/t/ography's "loss, shift and rupture" ([3], p. 898) as criteria and all of the difference that practice-based work makes to this text, the difference made in the doing: that is to say the making as well as the writing of our work [27]. Yet our work is not just about methodology, but also about epistemologies and ontologies. In working our layers of red writing and image-making we have accumulated a body of knowledge: a way of seeing red. This text embodies obsessive, excessive and passionate ways of knowing and understanding alongside congruent methods of researching our world(s). Both a poetics and physics of agency have been brought to bear here, sharing as they do, a life at the borders of current post-colonial literary [15], post-structural and scientific theory $[10,11]$ where matter matters and human and non-human agencies co-exist in both the same, and multiple realities. Barad [10] warns against an uncritical transfer of theories across disciplines, but we are not advocating an undisciplined purloining of theoretical positions, or suggesting quantum physics and magic as analogies or mirrors of each other, rather we are offering layered literary (arts-informed, aesthetic) and physical (environment-based, scientific) realisms as converging refractions of the new material turn.

We conclude with two final texts, our final textual disruptions of our red method. One is a poem, one a narrative; one is an embrace of red, the other, an apparent refusal. This rhythm too was part of the affective labour entailed in our collaborative work together.

Figure 15. Piece of wall; Marina Abramović's red lips; walk of the divining pin.

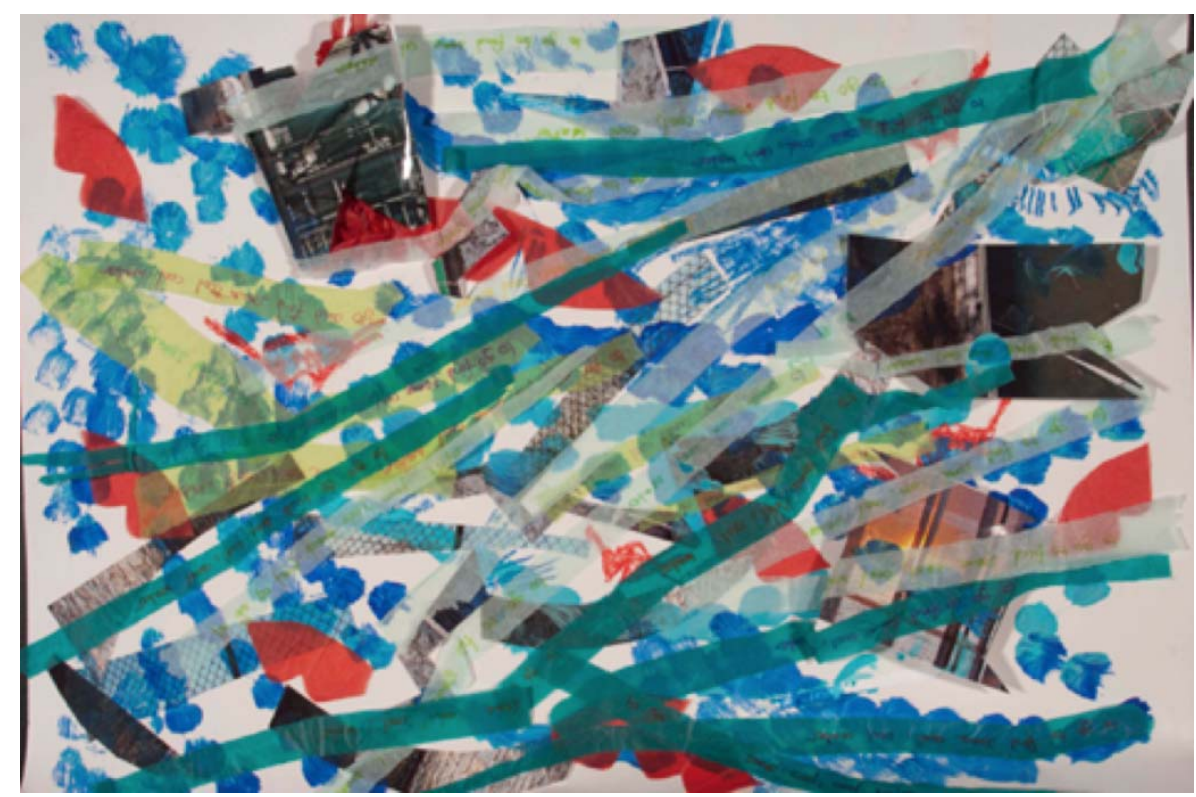


Seeing red, she came up the ramp on Sunday morning after her good night's sleep

and there it was, unfurled boldly across the room...

The long red banner

emblazoned with icons in red and gold and sticky-lipped kisses,

dripping with stick-ons and stand-ups, some

hanging off and others loitering at the joins,

She had slept through the silence whilst

in the chamber beneath her the world had caught fire.

There were flying red pigs or were they cows and crocodiles, Lacoste perhaps?

And pages torn from ancient books,

Of spells and kells, with hanging Babylonian pages, falling at angles off the edges,

And all manner of texts within texts without texts...

When all of life's a text, and all the texts are red,

what's next?

Figure 16. Red collage roundel.

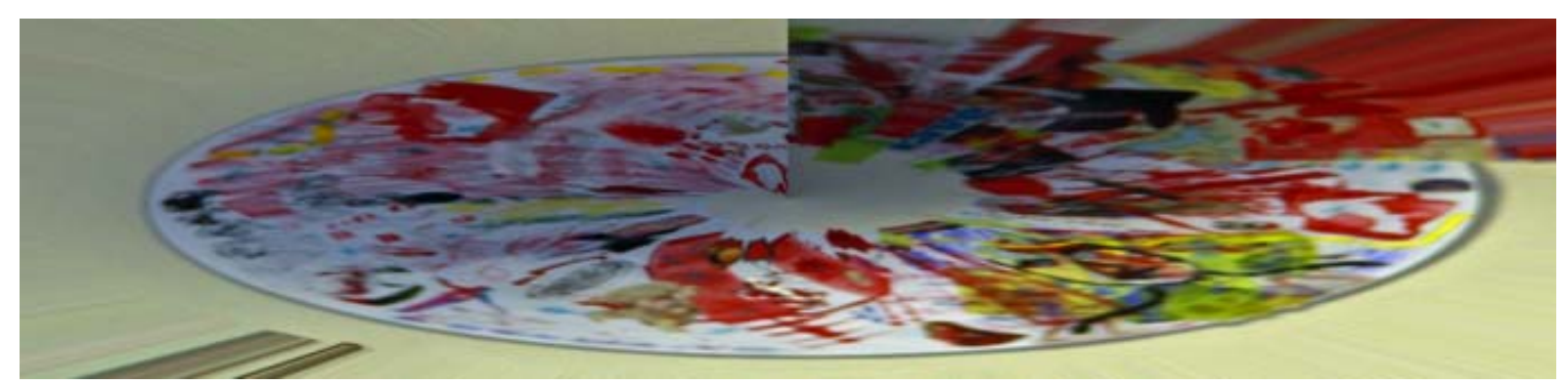

They sat opposite each other; the kitchen was suffused with warmth and light from the stove. There was a bottle of wine on the table between them. They shared a mood of shadow and latent intensity.

'I don't do red.'

The stark finality of that assertive performative utterance; disclosing an obtuseness, a finality that didn't seem to sit with how she understood his normally generous, compliant and fluent way with the world.

'Red is so crude, so obvious, I can't live with its pervasiveness and the way in which it infects the world with its dominant and dominating aspirations.'

She was taken aback by his directness; to assert such a strong denial and rejection of what she felt was the obvious warmth and geniality of that colour simply seemed to heighten this suddenly apparent and revealed contrariness, his stubborn refusal to accept and his increasingly frequent inclinations to thinly veiled anger and a growing tendency to awkwardness.

They sat silent for long minutes. He seemed glazed and uncommunicative. She found herself basking in barely dreamed landscapes of warmth, in which the indistinctness of objects were further blurred by their glowing auras of red.

'Red; it's so fuckin' atonal.' 
She reeled with shock at his directness as he spat his words across the table and was surprised by the venomous passion with which he blurted them out.

They continued sitting, obliquely facing each other: their quietness returned.

The bottle of red wine that sat between them on the worn wood of the kitchen table seemed to become more inviting to her. Her feeling of dis-ease, which seemed to grow, prompted, at least in part, by the fierceness of his outbursts, seemed to make her thirsty. Without looking at him, she leaned across the space between them; she sensed an electricity in her arm, cutting through the shimmering intensity of the force field humming between them; feeling suddenly energised she re-filled their glasses and eased back in her chair and looked across at him.

'I hate the imperialism of red and I hate the discursive force of the way in which it colonises senses of colour, reducing, blunting and actually dis-colouring through the very processes which lead to its existence.'

Figure 17. Ammerdown collective scroll, purposeful play with red II.

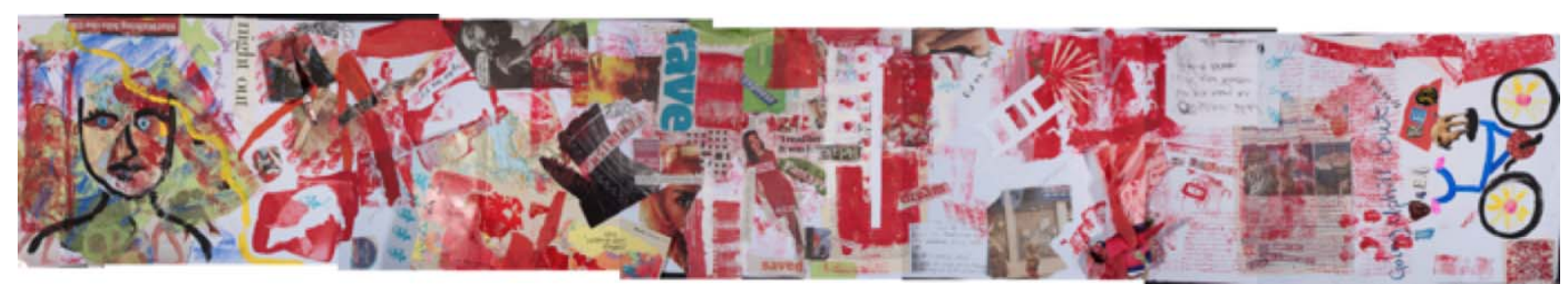

\section{Acknowledgments}

The images in this paper were created by Ken Gale, Mike Gallant, Susanne Gannon, Davina Kirkpatrick, Marina Malthouse, McClain Percy, Maud Perrier, Sue Porter, Ann Rippin, Artemi Sakellariadis, Jane Speedy, Jonathan Wyatt, Tessa Wyatt.

We would like to thank in particular the facilitators of the artmaking space, Davina Kirkpatrick and Tess Wyatt, who supplied materials, technical expertise and aesthetic reassurance to all the workshop participants.

We would also like to thank Susanne Gannon for the prompts and provocations for writing and Ammerdown Conference Centre and the Narrative Inquiry Centre, GSoE.

\section{Conflict of Interest}

The authors declare no conflict of interest.

\section{References and Notes}

1. Bronwyn Davies, and Susanne Gannon, eds. Doing Collective Biography. Maidenhead: Open University Press, 2006.

2. Kathleen Stewart. "Weak theory in an unfinished world." Journal Of Folklore Research 45, no. 1 (2008): 71-82.

3. Stephanie Springgay, Rita L. Irwin, and Sylvia Wilson Kind. "A/r/tography as living inquiry through art and text." Qualitative Inquiry 11, no. 6 (2005): 897-912. 
4. Alice Hoffman. The Ice Queen. London: Vintage books, 2006.

5. Ali Shaw. The Girl with the Glass Feet. New York: Henry Holt, 2010.

6. Susanne Gannon, Susan Walsh, Michele Byers, and Mythili Rajiva. "Deterritorializing collective biography." International Journal of Qualitative Studies in Education, online first, 2012. doi:10.1080/09518398.2012.737044.

7. Wikipedia. "Red string of fate.” Available online: http://en.wikipedia.org/wiki/Red_string_of_fate (accessed on 16 November 2012).

8. Ericka Johnson. "Simulating Medical Patients and Practices: Bodies and the Construction of Valid Medical Simulators.” Body \& Society 14, no. 3 (2008): 105-28.

9. John Law, and Vicki Singleton. “Object Lessons.” Organization 12, no. 3 (2005): 331-55.

10. Karen Barad. Meeting the Universe Halfway, Quantum Physics and the Entanglement of Matter and Meaning. Durham: Duke University Press, 2007.

11. Karen Barad. "Re(con)figuring Space, Time and Matter." In Feminist Locations: Global and Local, Theory and Practice. Edited by Marianne DeKoven. New Brunswick: Rutgers University Press, 2001, 75-109.

12. Bronwyn Davies, and Susanne Gannon. "Collective biography and the entangled enlivening of being." International Review of Qualitative Research 5, no. 5 (2012): 357-76.

13. Victoria Finlay. Colour: Travels through the Paintbox. London: The Folio Society, 2009.

14. Maggie Ann Bowers. Magic(al) Realism. London: Routledge, 2004

15. Jane Bennett. Vibrant Matter: A Political Ecology of Things. Durham: Duke University Press, 2010.

16. Alejo Carpentier. "On the marvelous real in America." In Magical Realism, THEORY, History, Community. Edited by Wendy Faris and Lois P. Zamora. Durham: Duke University Press, 1995, $75-88$.

17. Beatus of Liebana. "Silos apocalypse." British Library: Illustrated Manuscripts, Spain, 776. Available online: http://www.bl.uk/learning/cult/sacredbooks/religiousbooks/christian/silasapocaly pse1/silosapocalypse.html (accessed on 16 November 2012).

18. Helene Cixous, and Mireille Calle-Gruber. Rootprints: Memory and Lifewriting. London: Routledge, 1997.

19. Patricia Ticineto Clough. "Introduction." In The Affective Turn: Theorizing The Social. Edited by Patricia Ticineto Clough with Jean Halley. Durham: Duke University Press, 2007, 1-33.

20. Victor Turner. "Dewey, Dilthey and Drama, An essay in the anthropology of experience." In The Anthropology of Experience. Edited by Victor W. Turner, and Edward Bruner. Chicago: University of Illinois Press, 1986, 33-44.

21. Clifford Geertz. The Interpretation of Cultures. New York: Basic Books, 1973.

22. Gilles Deleuze. Negotiations, 1972-1990. New York: Columbia University Press, 1995.

23. Sarah Pink. Doing Sensory Ethnography. London: Sage, 2009.

24. Sarah Pink. "Multimodality, multisensoriality and ethnographic knowing: social semiotics and the phenomenology of perception.” Qualitative Research 11, no. 3 (2011): 261-76.

25. Jennifer Roswell. "Carrying my family with me: artifacts as emic perspectives." Qualitative Research 11, no. 3 (2011): 331-46. 
26. Pil Kollectiv, and Galia Kollectiv. "Can Objects Perform? Agency and Thingliness in Contemporary Sculpture and Installation.” Sculpture and Performance Conference, Henry Moore Institute and TATE Liverpool, Liverpool, UK. 24 March 2010. http://www.kollectiv.co.uk/Object $\% 20$ Orientations.html.

27. Estelle Barratt, and Barbara Bolt, eds. Practice as Research: Approaches to Creative Arts Enquiry. London: Tauris, 2009

(C) 2013 by the authors; licensee MDPI, Basel, Switzerland. This article is an open access article distributed under the terms and conditions of the Creative Commons Attribution license (http://creativecommons.org/licenses/by/3.0/). 